\title{
AN ACCOUNT OF NEPENTHES AMPULLARIA JACK
}

RICHARD NUNN • Malvern • South Australia • Richardjnunn1@gmail.com

Introduction

One of the most iconic and unique species of Nepenthes, N. ampullaria (Fig. 1) is widespread being found throughout South East Asia. As a young child enthusiastically reading everything available on Carnivorous Plants, the author recalls the amazement at seeing the clusters of tub shaped pitchers on the floor of the Bornean jungle, in a 1960s National Geographic. Many years later this amazement had not diminished on the first sight of this species in the field, just outside of Kuching, in Sarawak. Few fail to be impressed with N. ampullaria in cultivation or in the field and Lloyd's (1942) translation of Troll's (1932) first encounter with this species, sums up well how most feel when first confronted with $N$. ampullaria.

"I came across $N$. ampullaria among the massive vegetations [sic] of a swamp-forest on the island of Siburut [sic] off the west coast of Sumatra. It was a fabulous, unforgettable sight. Everywhere, through the network of lianas the peculiarly formed pitchers of this species gleamed forth, often in tight clusters; and, most remarkably, the muddy, moss overgrown soil was spotted with the pitchers of this plant, so that one got the impression of a carpet."

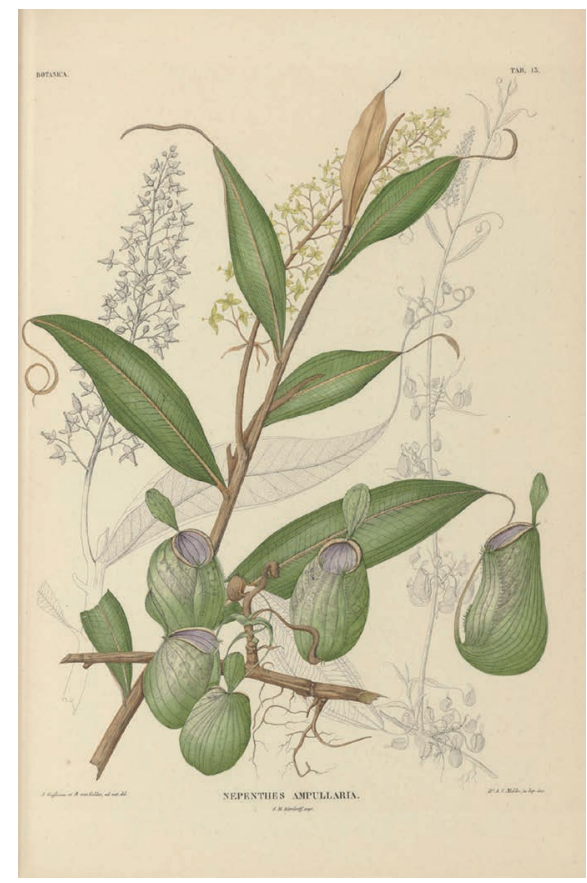

Figure 1: An early botanical illustration of Nepenthes ampullaria. This illustration was included in Korthals' 1839 monograph of the genus Nepenthes.

Apart from the unique shape of the pitchers, this species possesses other qualities that add to its fascination. Over the entirety of its range, Nepenthes ampullaria shows spectacular diversity in pitcher coloration, even though morphologically there is very little variation. It is also one of a small number of Nepenthes species that have evolved away from being solely carnivorous and can supplement their diet with forest canopy detritus.

Nepenthes ampullaria is an extraordinary member of the Nepenthes family and the aim of this short paper is to introduce the reader to a more in-depth appreciation of this wondrous plant.

\section{Etymology}

The specific epithet is derived from the Latin ampulla (flask), referring to the unique urceolate shape of the lower pitchers (Figs. 2-4, and Back Cover). 


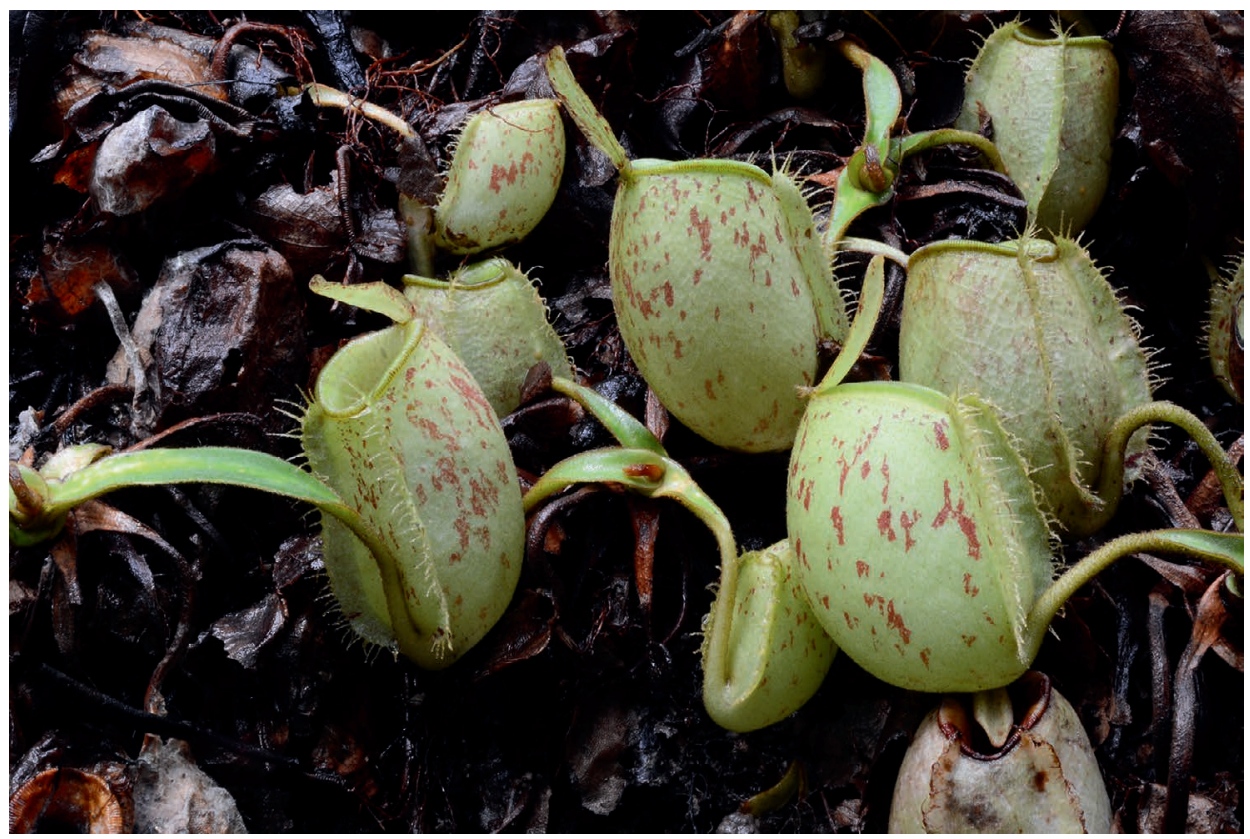

Figure 2: Nepenthes ampullaria growing at Kent Ridge, Singapore. Jack first discovered this species in Singapore in 1819. Photo taken by Richard Nunn.

\section{Botanical History}

Nepenthes ampullaria was discovered in Singapore, in 1819 by Dr. William Jack. Jack was employed by the East India Company as a surgeon in India, where he corresponded extensively with botanist Nathaniel Wallich. In 1818, he accompanied Stamford Raffles to Sumatra where he extensively documented the rich flora of that region until his death in 1822. Much of his work, including manuscripts, drawings, and collections were destroyed by fire in 1824. He died at Bencoolen (Bengkulu) in Sumatra on 15 September 1822. Before his death, Jack authored Descriptions of Malayan Plants 1820-1822, which were originally published in Malayan Miscellanies, in which he described $N$. ampullaria, and these were reprinted in various forms at later dates. One of these reprints containing the description of $N$. ampullaria, was formally published by William Jackson Hooker (1835), in Companion to the Botanical Magazine. This is now the accepted formal publication of this species.

\section{Description}

(Reproduced from Cheek and Jebb (2001))

Terrestrial climber to $15 \mathrm{~m}$ tall, with many terrestrial and some aerial rosettes. Stem cylindrical, 1-1.5 cm diam., internodes $1.5-7 \mathrm{~cm}$ long. Leaves sessile or with a short, poorly defined petiole, blade thickly chartaceous, lanceolate to spathulate; rosette leaves $2-5$ by $0.5 \mathrm{~cm}$, climbing leaves c. 25 by $6 \mathrm{~cm}$; apex acute, rarely acuminate, base attenuate, clasping the stem by $1 / 2$ its circumference. Longitudinal nerves 3-5 on each side of the midrib, in the outer $1 / 3$ or $1 / 2$. Pennate nerves numerous, oblique, straight, nearly reaching the margin. Lower Pitchers obliquely urceolate, semicircular on dorsal side, almost flat ventrally, to 10 by $9 \mathrm{~cm}$, with two fringed wings to $1.5 \mathrm{~cm}$ broad, 

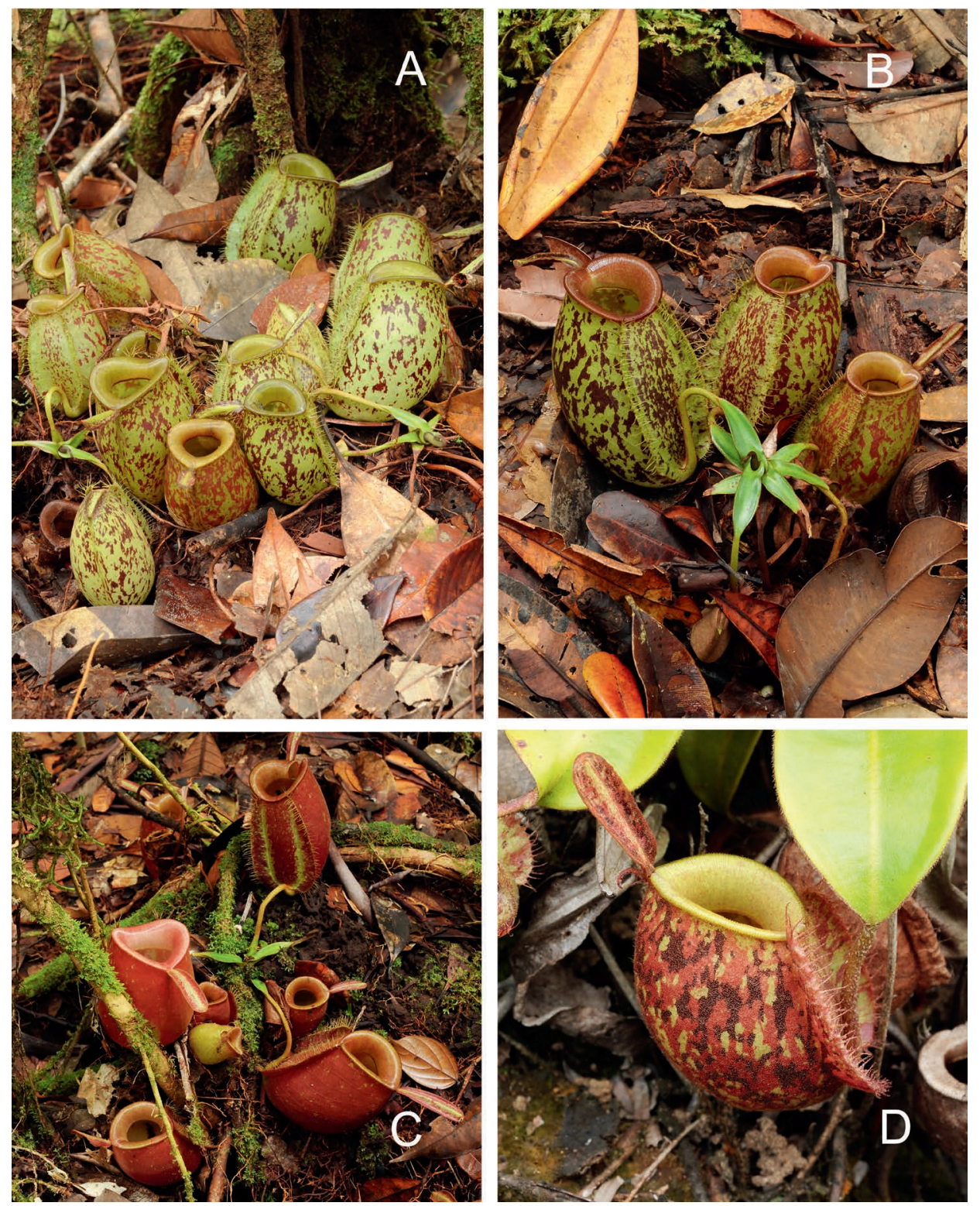

Figure 3: (A) A typical dense cluster of lower pitchers of Nepenthes ampullaria. (B) Colorful lower pitchers growing amongst leaf litter and other canopy debris. (C) An all red form. (D) Occasionally tri-color forms exist. Plants in photos A, B, C are growing in Gunung Mulu National Park, Borneo; photo D plant is growing at Kutching, Borneo. Photos taken by Richard Nunn.

the fringe elements $0.5-1 \mathrm{~cm}$ long, $0.2 \mathrm{~mm}$ apart; mouth oval, almost horizontal, straight; peristome flattened, to $1.5 \mathrm{~cm}$ wide, and sloping steeply inwards; lid narrowly oblanceolate, to 4 by $1.5 \mathrm{~cm}$, apex rounded, base cuneate, lower surface lacking appendages, nectar glands extremely sparse, 

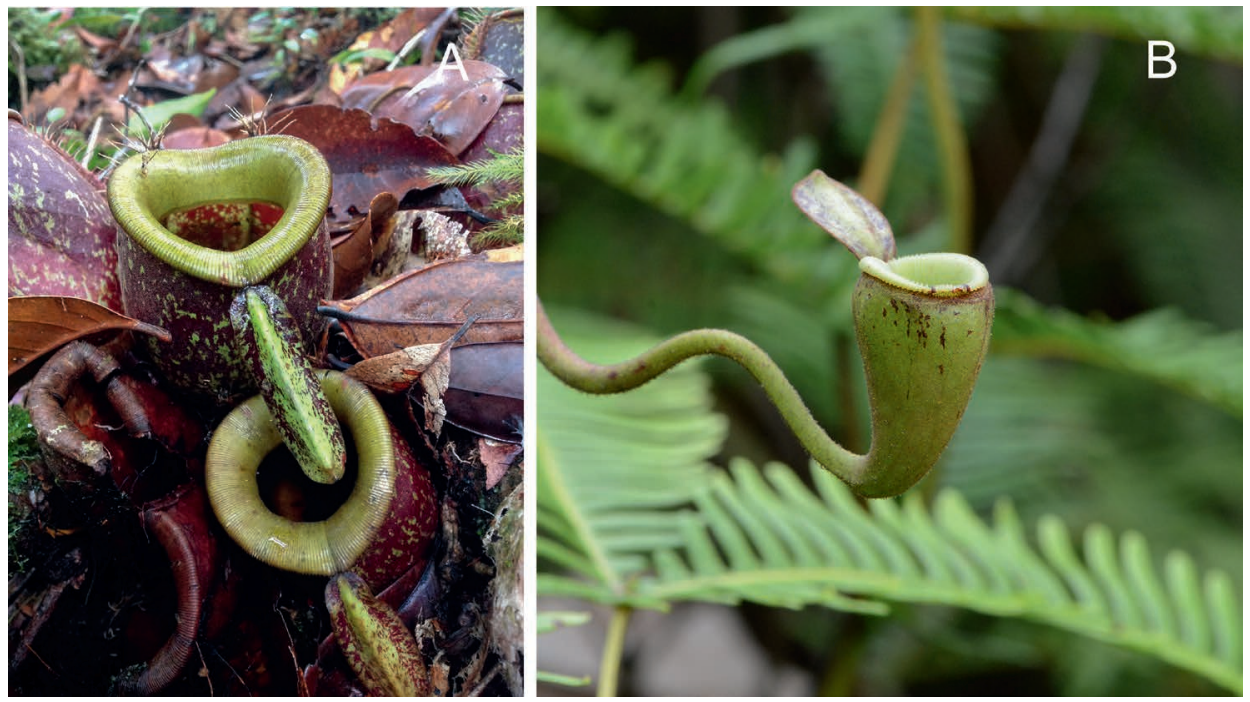

Figure 4: (A) Nepenthes ampullaria occurs at higher elevations in New Guinea. These lower pitchers are growing at $530 \mathrm{~m}$ asl on Mt. Angemuk. Photo taken by Alastair Robinson. (B) A rare upper pitcher photographed at Sibolga, Sumatra. Photo taken by Richard Nunn.

usually 6-12, sometimes absent, orbicular, broadly bordered, 0.4-0.5 mm diam., central pore c. 0.1 mm diam.; spur simple or branched, up to c. $10 \mathrm{~mm}$ long. Upper Pitchers generally not developed, rudimentary, broadly infundibuliform, c 2 by $2 \mathrm{~cm}$. Male inflorescence a panicle to 40 by $4-5 \mathrm{~cm}$; peduncle $2.5 \mathrm{~cm}$ long, $3 \mathrm{~mm}$ diam. At base; partial peduncle $8-12(-50) \mathrm{cm}$ long, fasciculate at apex, (1-)3-6(-10)-flowered; bracts foliose, spathulate, 12-14 by $4-5 \mathrm{~mm}$, inserted $0-2 \mathrm{~mm}$ from base of partial peduncles; pedicels 7-8 mm long; tepals broadly elliptic, $4-5$ by $3-5 \mathrm{~mm}$, androphore 3-5 $\mathrm{mm}$ long; anther head 2 by $1.5 \mathrm{~mm}$. Indumentum densely velvety in young parts, under leaf blades, especially margins, on young pitchers and on the inflorescence; hairs red or brown, mostly simple, $0.3 \mathrm{~mm}$ long. Colour of pitchers usually green, deeply flecked with maroon, rarely entirely red, sometimes almost whitish yellow, with pale pink flecks, likewise the leaves of these pitchers may be a pale yellow-pink if buried beneath leaf litter; tepals green to yellow; indumentum deep red.

\section{Distribution and Ecology}

One of the most widespread Nepenthes species, N. ampullaria is found in Borneo, the Maluku Islands, New Guinea, Peninsular Malaysia, Singapore, Sumatra, and Thailand. It has also been recorded from many smaller islands in the region. Nepenthes ampullaria generally grows in damp, shady forest from sea-level to $2100 \mathrm{~m}$.

In Borneo, it occurs at elevations of 0 to $500 \mathrm{~m}$ on relatively flat terrain in kerangas forest, peat swamp forest, and degraded swamp forest (Clarke 1997).

In Sumatra and Peninsular Malaysia, it grows from sea-level to $1100 \mathrm{~m}$ elevation on flat terrain in heath forest, padang, peat swamp forest, and degraded swamp forest (Clarke 2001).

Populations found above $1700 \mathrm{~m}$ are restricted to New Guinea (McPherson 2009), where this species favors Araucaria forests, open microphyllous vegetation and swamp grassland (Jebb \& Cheek 1997). 
Nepenthes ampullaria readily hybridizes with other lowland Nepenthes species with which it grows. The following species have been recorded as hybridizing with $N$. ampullaria: $N$. albomarginata, $N$. bicalcarata, N. eustachya, $N$. gracilis, N. hemsleyana, N. hisuta, N. mirabilis, N. neoguineensis, $N$. rafflesiana, $N$. reinwardtiana, $N$. spathulata, and $N$. tobaica. Hybrids with $N$. gracilis and $N$. rafflesiana were for a long time thought to be distinct species and were described and published as N. trichocarpa and N. hookeriana, respectively (Fig. 5).

\section{Sources of Nutrients}

Clarke (2001) suggests that Nepenthes ampullaria has developed strategies for obtaining sources of nitrogen other than from insects. This species is unusual in that it has evolved growing in shade beneath the forest canopy, where it receives a constant stream of debris, including twigs, dead leaves and flowers, and scat from above. Moran et al. (2003) estimate that $N$. ampullaria plants growing under the forest canopy derive $35.7 \%( \pm 0.1 \%)$ of their foliar nitrogen from leaf litter. The author has observed this first hand at Kent Ridge in Singapore and Gunung Murud National Park, where populations of $N$. ampullaria are covered by a layer of detritus from the canopy above, often with just the pitcher mouth visible.

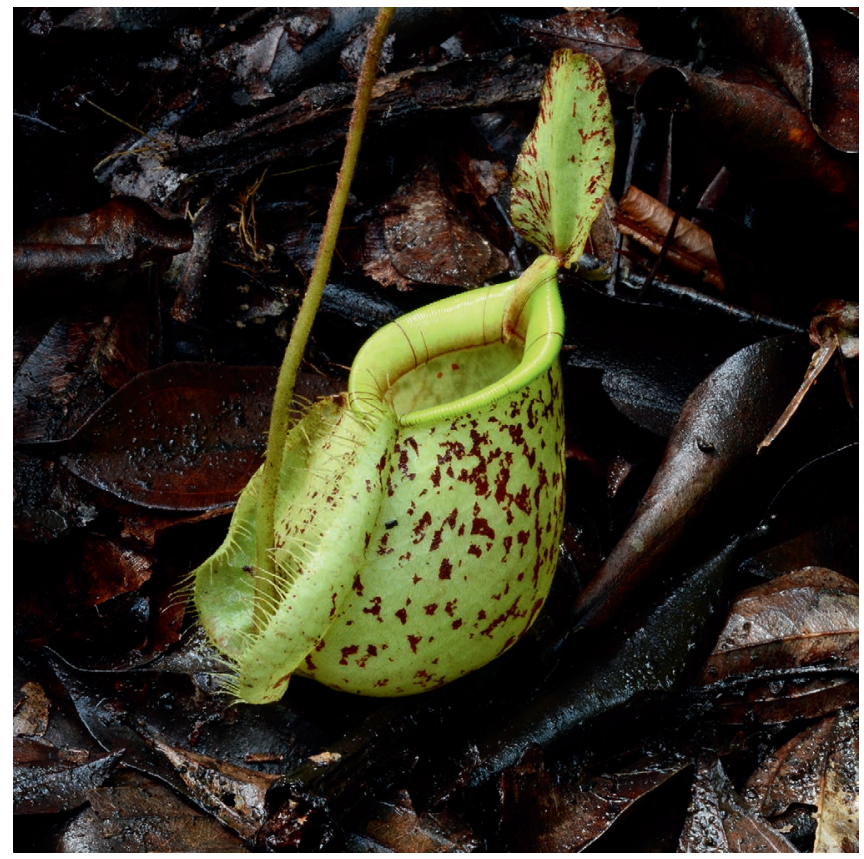

Figure 5: A natural hybrid between Nepenthes ampullaria and $N$. rafflesiana, $N \times$ hookeriana growing at Kent Ridge, Singapore. Photo taken by Richard Nunn. 
Clarke (2001) points out that Nepenthes ampullaria has developed several unique adaptations as a result of evolving to consume canopy debris.

1. The pitcher lid is vestigial and reflexed away from the pitcher mouth, allowing debris to fall directly into the pitcher.

2. Nectar glands, an important component in prey attraction, are rare or absent from the pitcher lid.

3. In terrestrial pitchers, the glandular region extends almost to the peristome, so that there is little or no conductive waxy zone.

4. Nepenthes ampullaria pitchers lack "lunate" cells, the modified stomatal guard cells, which may deny prey a foothold in the pitcher (Lloyd 1942).

5. The plant's deployment of pitchers is unusual for the genus, often forming a "carpet" of pitchers covering the substrate, hence maximizing the area to capture falling debris.

6. The pitchers of $N$. ampullaria are relatively long-lived (remaining functional on average for 6 months), as a result of a relatively slower accumulation of nutrients.

\section{Infauna}

Pitcher plants not only utilize insects for nutrients, they also create their own ecosystem that supports other creatures. Phillips et al. (2008) record that several infaunal species have been recorded from the pitchers of $N$. ampullaria. Most notably one of the smallest known species of Old World frog, Microhyla nepenthicola, and the crab spider, Misumenops nepenthicola.

\section{Conservation Status}

Based on IUCN criteria Nepenthes ampullaria is rated least concern, due to its widespread distribution, also many populations are found in protected National Parks. Despite this, it is worth noting that in Peninsular Malaysia, Borneo, and Indonesia in particular, lowland forest is being cleared at an alarming rate to make way for real estate development, palm oil plantations, and other commercial crops.

\section{Cultivation}

Nepenthes grow in a wide range of habitats and ecosystems, Nepenthes ampullaria is considered a lowland species and although found above $500 \mathrm{~m}$ in some locations, predominantly grows between 0-500 $\mathrm{m}$ in tropical areas. What follows are basic guidelines only because every grower will have different variations on these themes that suit their individual conditions. If one is lucky enough to live in lowland tropical areas, Nepenthes ampullaria can be grown successfully outdoors in bright indirect light. The author grew many fine specimens on his balcony in Singapore over a 3-year period.

Light: This input is one of the most important in producing optimal pitcher size and coloration. As a guide, a bright position with high indirect light is best, although Nepenthes ampullaria do tend to grow in more shade than other species. If plants are grown under shade cloth, a level from $50 \%$ up to about $80 \%$ produces good results. The length of the daylight hours in their natural habitat is generally around 12-13 hours.

Moisture: Nepenthes like to be kept moist and N. ampullaria is no exception. Misting for a few minutes several times a day with good quality water and hand watering once every few days is enough. 
Humidity: In a greenhouse, humidity around the plants is usually maintained to an acceptable level by their moist potting medium with the plants growing well with the fluctuating humidity levels that normally occur during the day. These levels usually range from $50-70 \%$ during the day and up to $100 \%$ at night. While plants growing in an outside environment will experience lower humidity levels than this, as long as the potting media is kept moist, the plants will be happy.

Temperature: This is probably the most important variable for successful growth of this species. In lowland tropical areas, the temperature range is remarkably stable, with daytime temperatures around $30^{\circ} \mathrm{C}$ and night rarely dropping below $24^{\circ} \mathrm{C}$.

Media: This is a controversial topic as every grower will have their own special combination and swear by its effectiveness. A mix of quality orchid bark and long fiber Sphagnum, with some coarse perlite has proven very successful.

Nutrients: Insects are the best source of nutrients, however in cultivation a dilute mix of orchid fertilizer every few weeks is beneficial.

\section{References}

Cheek, M.R., and Jebb, M.H.P. 2001. Nepenthaceae. Flora Malesiana 15: 1-157.

Clarke, C.M. 1997. Nepenthes of Borneo. Natural History Publications (Borneo), Kota Kinabalu.

Clarke, C.M. 2001. Nepenthes of Sumatra and Peninsular Malaysia. Natural History Publications

(Borneo), Kota Kinabalu.

Hooker, W.J. 1835. Description of Malayan plants by William Jack with a brief memoir of the author and extracts from his correspondence. Companion to the Botanical Magazine 1: 121-147.

Jebb, M.H.P. 1991. An account of Nepenthes in New Guinea. Science in New Guinea 17(1): 7-54.

Jebb, M.H.P., and Cheek, M.R. 1997. A skeletal revision of Nepenthes (Nepenthaceae). Blumea 42(1): 1-106.

Korthals, P.W. 1839. Over het geslacht Nepenthes. In: C.J. Temminck 1839-1842. Verhandelingen over de Natuurlijke Geschiedenis der Nederlandsche overzeesche bezittingen; Kruidkunde. Leiden. pp. 1-44. Lloyd, F.E. 1942. The Carnivorous Plants. Chronica Botanica 9. Ronald Press Company, New York. McPherson, S.R. 2009. Pitcher Plants of the Old World. 2 volumes. Redfern Natural History Productions, Poole.

Moran, J.A., Clarke, C.M., and Hawkins, B.J. 2003. From carnivore to detritivore? Isotopic evidence for leaf litter utilization by the tropical pitcher plant Nepenthes ampullaria. International Journal of Plant Sciences 164(4): 635-639. doi:10.1086/375422

Phillipps, A., Lamb, A., and Lee, C.C. 2008. Pitcher Plants of Borneo. Second Edition. Natural History Publications (Borneo), Kota Kinabalu.

Troll, W. 1932. Morphologie der schildförmigen Blätter. Planta 17: 153-314.

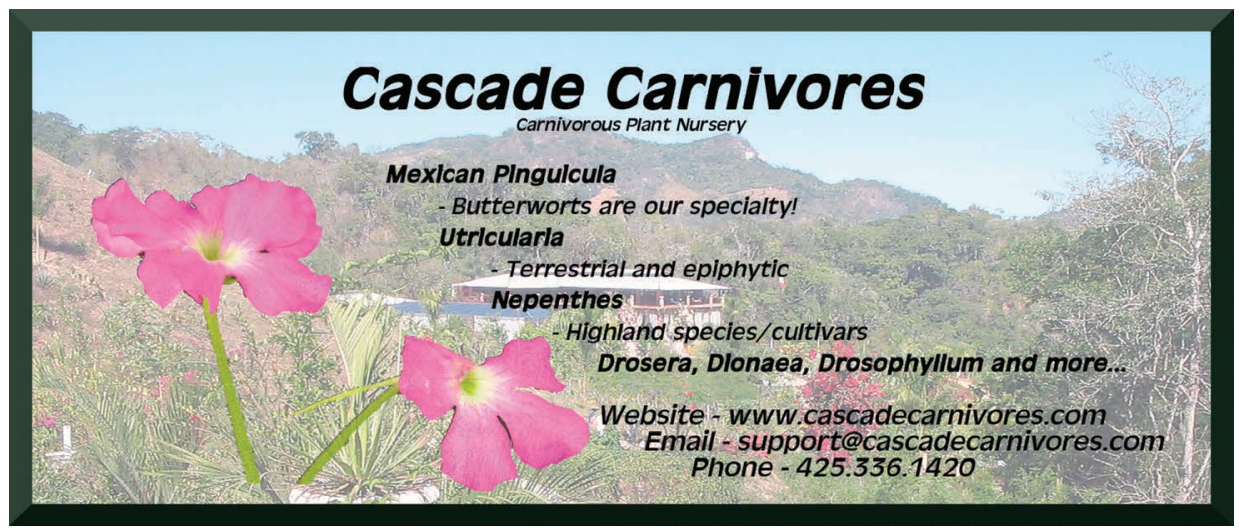




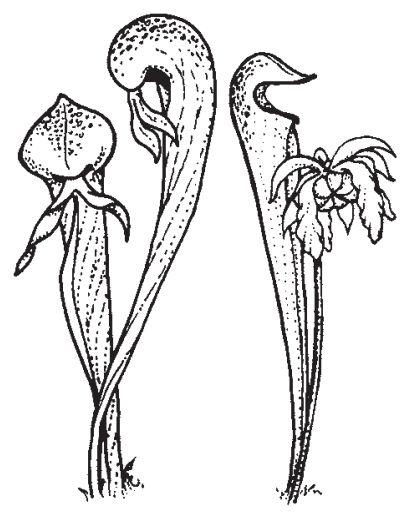

\section{CARNIVOROUS \\ PLANT \\ NEWSLETTER}

Journal of the International

Carnivorous Plant Society

www.carnivorousplants.org

Volume 47, Number 2 June 2018

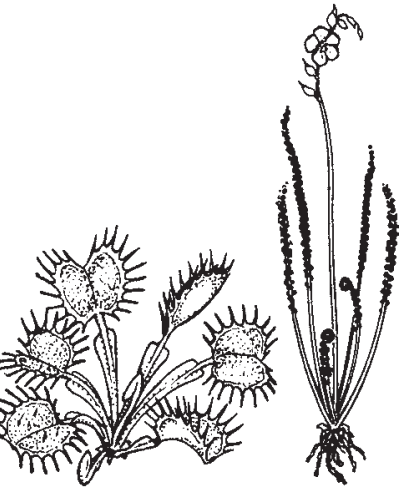

\section{Front Cover: Flowering African Aldrovanda vesiculosa from Botswana in an indoor culture. Photo by Lubomír Adamec. Article on page 64.}

\section{Back Cover: A cluster of Nepenthes ampullaria lower pitchers growing in Gunung Mulu National Park, Borneo. Photo taken by Richard Nunn. Article on page 47.}

Carnivorous Plant Newsletter is dedicated to spreading knowledge and news related to carnivorous plants. Reader contributions are essential for this mission to be successful. Do not hesitate to contact the editors with information about your plants, conservation projects, field trips, or noteworthy events. Advertisers should contact the editors. Views expressed in this publication are those of the authors, not the editorial staff.

All correspondence regarding dues, address changes and missing issues should be sent to the Membership Coordinator at the ICPS. Do not send such correspondence to the editors. Checks for subscriptions should be made to the International Carnivorous Plant Society in US funds. Dues, including a subscription, are \$30 per year.

International Carnivorous Plant Society, Inc.

2121 N. California Blvd., Suite 290

Walnut Creek, CA 94596-7351, USA

icps@carnivorousplants.org

President

Vice President

Secretary

Treasurer

Board Member

Board Member

Board Member

Membership Coordinator

Webmaster

Media Coordinator

Seed Bank Manager

CPN Editors

Managing Editor

Editor

Editor

Editor

Science Editor

Science Editor

\author{
Marcel van den Broek, marcel@carnivorousplants.org \\ Richard Nunn, richardnunn@carnivorousplants.org \\ Keith Becker, keith@carnivorousplants.org \\ Ryan Ward, ryan@carnivorousplants.org \\ Alex Eilts, Conservation Director, alex@carnivorousplants.org \\ Jan Schlauer, Cultivar Registrar, jan@carnivorousplants.org \\ Bob Ziemer, bob@carnivorousplants.org \\ Carolyn Becker, carolyn@carnivorousplants.org \\ John Brittnacher, john@carnivorousplants.org \\ ChadWilliams, chad@carnivorousplants.org \\ Joe Griffin, joe@carnivorousplants.org \\ editor@carnivorousplants.org \\ Bob Ziemer \\ Barry Rice \\ Karl Herold \\ John Brittnacher \\ Fernando Rivadavia \\ Jan Schlauer
}

Date of effective publication of the March 2018 issue of Carnivorous Plant Newsletter: 1 February 2018.

The ICPS is the International Cultivar Registration Authority (ICRA) for the names of cultivated carnivorous plants according to the International Code of Nomenclature for Cultivated Plants. Send relevant correspondence to the ICPS, Inc.

Carnivorous Plant Newsletter is published quarterly in March, June, September, and December by the ICPS, Inc., 2121 N. California Blvd., Suite 290, Walnut Creek, CA 94596, USA. Periodicals postage paid at Walnut Creek, CA and additional mailing offices. Postmaster: Send address changes to ICPS, Inc., 2121 N. California Blvd., Suite 290, Walnut Creek, CA 94596, USA. Printed by Allen Press, Inc., 810 E. 10th Street, Lawrence, KS 66044. Logo and masthead art: Paul Milauskas. (C) 2018 International Carnivorous Plant Society. All rights reserved. ISSN \#0190-9215 


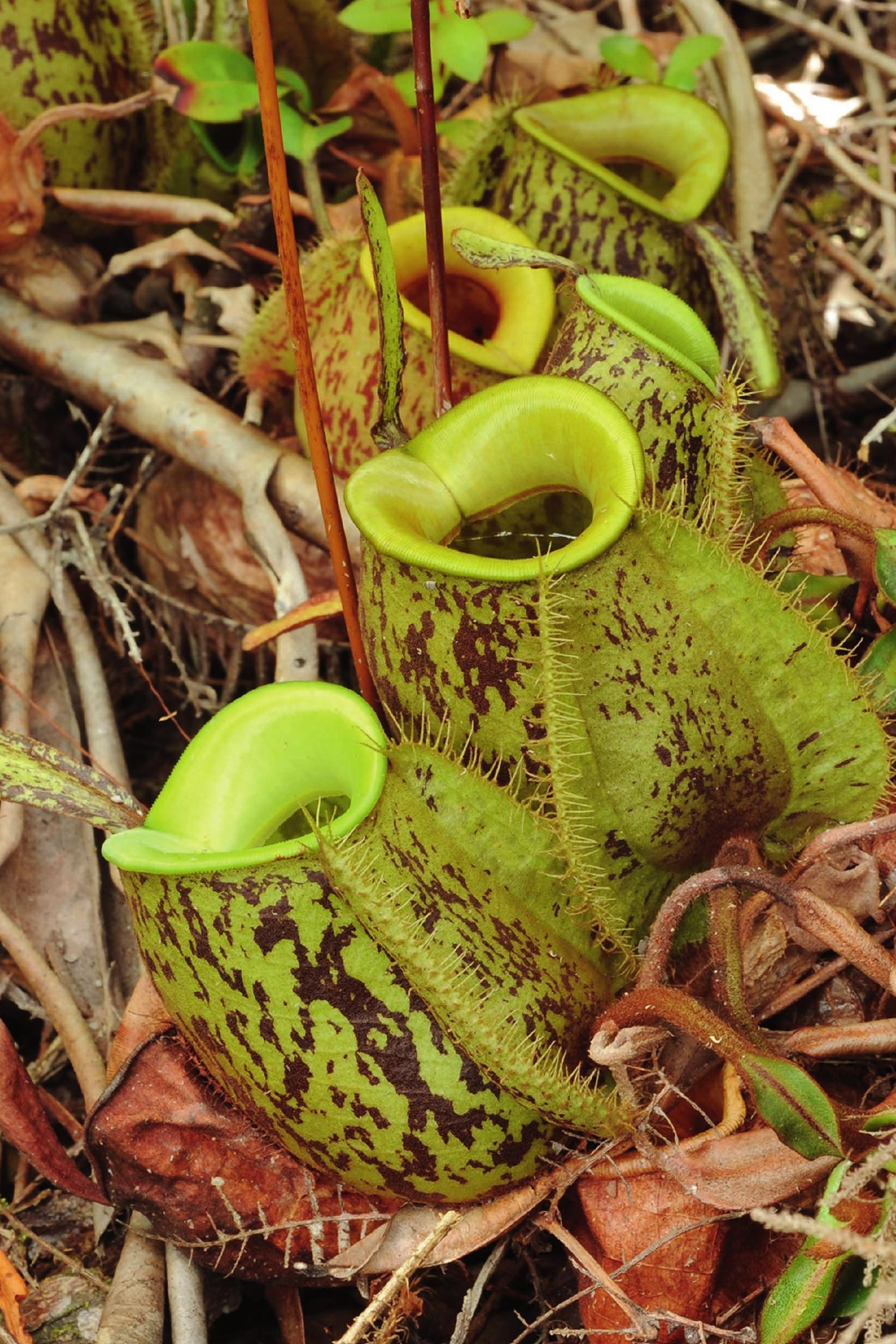

